\title{
FORMING COMFORTABLE MICROCLIMATE IN THE BUS COMPARTMENT VIA DETERMINING THE HEAT LOSS
}

\author{
Oleksandr Kravchenko ${ }^{1}$, Ivan Hrabar ${ }^{2}$, Juraj Gerlici ${ }^{3}$, Serhii Chuiko ${ }^{1}$, Kateryna Kravchenko ${ }^{3, *}$
}

${ }^{1}$ Department of Automobiles and Transport Technologies, Zhytomyr Polytechnic State University, Zhytomyr, Ukraine

${ }^{2}$ Department of Processes, Machines and Equipment, Polissya National University, Zhytomyr, Ukraine

${ }^{3}$ Department of Transport and Handling Machines, University of Zilina, Slovakia

*E-mail of corresponding author: kkatherina@ukr.net

\section{Resume}

Methodology of the heat outcome from the bus compartment in terms of duration factor of cooling and heating capacity is introduced. Value of the air temperature change in the compartment was calculated. The balance method of the spent heat is used to assess the level of keeping a proper temperature environment in the bus saloon when a comfortable microclimate is created for passengers via the proper conditioning system functioning. Models of the heat transmission notions were used for calculation regarding different categories of the heat load creation. A developed numeric algorithm was introduced in the article as well as a program for modelling the transitory heat processes in the compartment of the city bus equipped with an air-conditioner enabling to take into account various constructive decisions in the system of comfortable provision of city buses and model unstable heat processes.

\section{Article info}

Received 17 July 2020

Accepted 23 August 2020

Online 4 March 2021

\section{Keywords:}

city bus, compartment, temperature environment, heat capacity of air, heat balance, comfortable conditions

\section{Introduction}

The system of air-conditioning is an important subsystem in transport means regarding comfort support, in particular, in a while, for city buses. The heat loads, affecting a microclimate in a bus compartment while performing transport work, are rather difficult to determine due to processes of the turbulent stream and heat exchange. They consist of many thermal forms and undergo influence of many factors, such as outer temperature, intensity of sun radiation, materials for body cladding, number of passengers, motion velocity of transport means, geographic location etc. [1-3].

The microclimate in the bus compartment depends on the properties of the heating systems, ventilation, conditioning and the range of constructive parameters of the bus itself (tightness of the saloon, location of engine, its thermal insulation, heat conductivity of cladding materials, number of passengers, type of windows), as well.

The air humidity, along with temperature, may affect the human body substantially. As the doctors-hygienists state, the most favourable combinations for a human body are the conditions, when relative humidity equals $50 \%$ and the temperature is equal to 16 to $18^{\circ} \mathrm{C}$, [4].

The existing mathematical models of unstable heat processes in the city bus do not completely reflect the heat processes within the compartment with passengers inside [5]. Besides that, the unstable heat processes are often studied in the stable mode, when the heat streams and parameters of the heat circuit are constant and do not depend on time [6]. An important influence on heat exchange between outer temperature is imposed by the massive construction of the bus and due to that, the temperature fluctuations on its inner surfaces are decreased.

Due to appearance of the more effective technical solutions of the life support system, a necessity appears for creating the new mathematic apparatus that would enable to take into account these properties and their influence on the course of unstable heat processes during the whole time of performing the process of passengers' transportation.

The aim of the article comprises developing the method of solving the tasks regarding the system of comfortable provision of the city bus compartment via a suggested heat mode through the heat costs analysis.

To assess the efficiency of the conditioner functioning and to determine the period of its switching, while performing the passengers transportation process in the city route (at the example of the bus (MAZ - 206), a methodology of the heat balance calculation in the cycle "heating - cooling" was introduced. The experimental results of testing [7] by the modelling methodology [8] were used for mathematic modelling. A comparison of experimental testing and mathematic modelling was conducted. The method of elementary counterweight was 
used for solving the complex system of equations. The developed mathematic model of the heat processes in the city bus compartment, unlike the existing ones, enables to research unstable heating engineering indexes in the bus compartment, under different operation conditions (level of anisotropy) and compare the work of various systems of life support in terms of their constructive decisions.

\section{The latest research analysis}

Scientists, such as Zhukovskyi [5], Kulikov et al. [9], Matveev [10], Palutin [11] and others [3, 12-15] researched the requirements to climate systems and microclimate normalization of wheeled vehicles. However, the constructive decisions of modern buses equipment change with time. Conditions of their exploitation also differ between the types, especially in the cities due to insufficient speed modes of traffic and unstable driving.

Results of the design technology development and calculation of inner aerodynamics of the heating system and ventilation of a passenger car were introduced in [10]. The thermal resistance of each layer of surfaces of the roof, sidewalls and facings is proposed to be taken into account separately, via indexes of the heat dissipation, heat conductivity and heat perception. The calculation method of the air exchange in a car compartment was presented under the following conditions:

- $\quad$ equal temperature both inside and outside of the car;

- position of hatches and windows (open or closed) do not influence the character of -the air penetration into the car;

- $\quad$ excessive pressure in the car compartment is equal in all its volumes;

- $\quad$ air pressure in the compartment is established.

Parameters of the air environment of their compartments were determined due to the research of ventilation systems in cars' bodyworks [11]. Measurement of summing the effective surfaces of looseness enabled to access tightness of separate parts and a bodywork as a whole of some domestic and foreign cars. The conducted calculation of the air-exchange value in a bus saloon that have two rows of passenger double-seats and roof height of $196-205 \mathrm{~cm}$, resulted in the upper limit equal to $2000 \mathrm{~m}^{3} / \mathrm{h}$.

Analytical dependencies of the heat mode of the bus saloon during its motion, under conditions of the summer operation, were obtained in [5]. Influence of the air exchange through doorway at the stops and infiltration due to looseness of a bodywork was determined.

In calculating the loading on the intercity bus, radiation from windows was considered in the work [12], whereas the heat dissipation from roof, floor, back and front sidebars were taken into account via conductivity only. The maximum increase of heat was calculated as $25.96 \mathrm{~kW}$ at 17:00 during July, and this case is a peak loading and a peak time as heat dissipation. The temperature of outer atmospheric air in Adana city, in July, was accepted as $36^{\circ} \mathrm{C}$ and accordingly $25.7^{\circ} \mathrm{C}$ in the bus compartment.

In [13] was stated that the trip duration in a car and a factor of passenger loading have a sufficient impact on the perception of a comfort level by a driver and passengers.

The conducted research of scientists in [14] proved that the cars with venting of different colors have an excellent reflecting capacity of opaque elements of a bodywork. Regarding this, the indexes were developed in accordance with a certain color of opaque elements of a bodywork classified as solar reflection indexes (SRI) and were calculated considering the solar reflection and heat radiation. The measurements proved that the cold colors have the solar spectral reflecting ability much lower than the light tones. The solar reflection fluctuates within the range of 0.04 (usually black) up to 0.70 (usually white) with many cold sub tones from the solar reflection, approximately $0.20-0.50$. All the patterns with coating demonstrated a high thermal release (0.82 - 0.95).

It was proved by the authors of [15] that the efficient microclimate control in transport means is at least traditionally considered to serve the comfort, but under the negative effects of a temperature mode; it has a negative influence on a driver's efficiency and is considered as a safety factor in traffic. A great influence on a driver's alertness at temperature of $+27^{\circ} \mathrm{C}$ was established in comparison to temperature $+21^{\circ} \mathrm{C}$ in transport means: the drivers missed 50\% more signals given within the first hour and reaction time got for $22 \%$ longer at the increased temperature level.

The dominating parameter of a microclimate in a closed space is an air temperature that is stated by authors of [16].

The demands to the micro-climate of the bus saloons is changing due to the peculiarity of commissioning city buses, equipped by the conditioners, that used to be a comfort feature only for the intercity buses. Another approach to microclimate quality is required by the bus operation conditions during the city traffic jams and rationing fuel cost by that [7].

\section{Determination of the micro-climate in the city bus compartment}

\subsection{General characteristics of micro-climate provision in the saloon of the city shuttle bus}

One of the crucial factors of microclimate in the bus saloon at its ventilation is its air exchange providing a normalized temperature difference between the compartment and outer environment and mobility and humidity of indoor air. At the same time a necessary air exchange of the compartment is determined on conditions of assimilation of the heat input from the solar radiation and from the passengers [5]. The main requirement to the microclimate lies in supporting meteorological and sanitary parameters in the room. Meteorological parameters comprise temperature $\left(t_{a},{ }^{\circ} \mathrm{C}\right)$, relative humidity $\left(\varphi_{\mathrm{a}}, \%\right)$ 
and mobility $\left(\mathrm{v}_{\mathrm{a}}, \mathrm{m} / \mathrm{s}\right)$ of indoor air in the room; sanitary parameters include radiation temperature of surfaces $\left(\mathrm{t}_{\mathrm{r}},{ }^{\circ} \mathrm{C}\right)$, intensity of thermal (infrared radiation), level of noise, brightness, maximum permissible concentration of dust and gases [17]. The given statement corresponds to microclimate requirements of the city bus compartment to the full extent.

There are no unified requirements for the microclimate in the compartments of the city shuttle buses in the requirements to the products that undergo a compulsory certification in Ukraine. It is, primarily based on the lack of standards containing regulations to the given requirements. At the same time, among current standards of Ukraine comprising assessment of moderate and extreme thermal environments, the feeling of discomfort level (thermal dissatisfaction) of people in buildings and systems is reflected in the international standard ISO 7730:2005 [18].

Review and analysis of calculation methods for ventilation systems and heating showed that their basis lies in the integrated approach enabling to determine only average parameters implying assessment of local and linear expenditures. For example, regulatory document [19] regulates the air temperature in railway passenger carriages of all the types, in winter at the level of $+20^{\circ} \mathrm{C}$ $\pm 2^{\circ} \mathrm{C}$, and in summer $+24^{\circ} \mathrm{C} \pm 2^{\circ} \mathrm{C}$ (in the carriages with conditioners).

While operating the bus MAZ-206 on the city routes of the automobile enterprise one comes across the problem of rationing fuel costs while working with the conditioner. It relates to activating it under the conditions of providing the optimal microclimate able to change regardless of the temperature of the outer environment. It is caused by the seating capacity, motion conditions, management of setting the whole air conditioning system etc.

The thermal perception of a person in the bus saloon is affected mainly by four factors: air humidity and velocity, temperature and properties of the surfaces surrounding a person [10]. It is worthy to consider that though the heat perception is determined by the enumerated parameters, not any ratio of these parameters may provide comfortable conditions. Each of them may not be changed at random, but only within some appropriate limits that satisfy the conditions of a comfortable thermal perception while staying in the bus saloon. Knowledge of the permissible limits of temperature fluctuations, air humidity and mobility enables regulating application of some types of air conditioning systems.

\subsection{Factors of proper heat productivity and its systems}

The heat costs of the city bus compartment mainly depend on:

- the temperature difference between the bus saloon and outer environment (the bigger the difference, the higher the costs);

- the heat-protective properties of the bodywork constructions (sidebars and floor, window glass constructions and doors).

Optimal management of the conditioning system lies in the general regulation of compressor velocity that enables to control cooling power that can regulate the temperature to maintain comfort in the bus saloon and reduce the fuel consumption.

Power of air-cooling is determined by the thermal loading of the saloon and it is a complex process. It consists of many thermal forms depending on various factors: temperature of environment, solar energy intensity, material of constructions, number of passengers, motion speed of a transport means etc. [20-21].

To create the thermal comfort inside the bus it is necessary to take into account all the factors considered as they may change within time and at the same time consider the fact that each person percepts the conditions of being in the closed space inside the bus in a different way. As all the people are different, the thermal comfort usually refers to the set of optimal parameters where the highest percentage of the present passengers feel comfortable in the external environment.

As the environment inside the city bus while performing the transport process depends on many conditions, a transport means may not maintain a stable temperature inside the compartment, as it may not affect the time of opening and closing of doors, time of the day, trip duration, number of passengers and internal temperature.

The heat transmission is a complex process comprising separate processes of the heat dissipation in a hot and a cold heat bearer and heat transfer via the heat conductivity via the wall parting heat bearers. The bus saloon as any chamber is an anisotropic environment in various directions and with nonhomogeneous properties. This notion is characteristic for the heat conductivity [22].

The body surface of an average person is about $1.8 \mathrm{~m}^{2}$. Air and barriers of the room percept this heat. Consequently, the temperature of the room is an important factor characterizing a microclimate of the room and defines the state of thermal comfort in it. The temperature values of inner air for rooms of different application in cold and warm seasons are recommended by the norms (DBN and rules, EN ISO, ASHRAE etc.). Usually, temperature modes $+20^{\circ} \mathrm{C}$ to $22^{\circ} \mathrm{C}$, in the cold season and $+22^{\circ} \mathrm{C}$ to $25^{\circ} \mathrm{C}$ in the warm season are recommended as optimal [22].

\subsection{Approach to choosing experimental research method}

Calculation of the heat input via elements of the bus constructions cladding in the summer period is complicated by sufficient temperature fluctuations of outer air and even bigger fluctuations of the heat stream on outer surfaces from the solar radiation. At the same time, an especially important factor lies in the heat input from the present passengers that also depends on outdoor air parameters. Thermal insulation of air conduits, pipelines and bodywork 


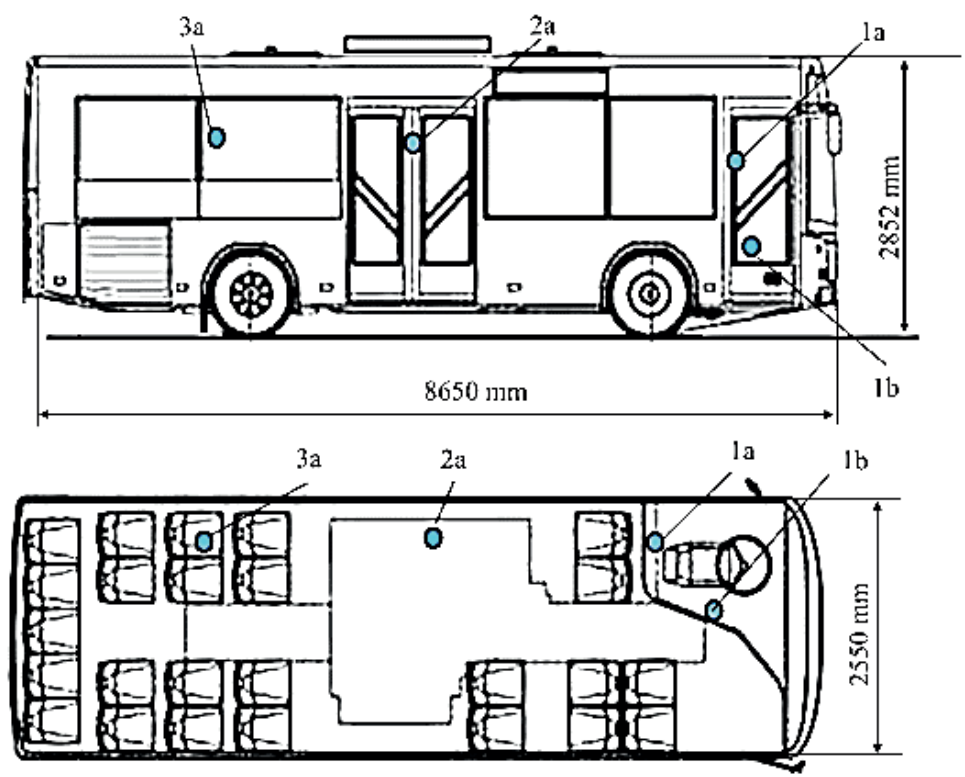

Figure 1 Points of measuring the temperature indexes in the bus compartment

construction generally caters to prevent heat and cold loss. Massiveness of the compartment's framing and noise and heat protective materials serve as a passive protection decreasing or increasing the peak loading that influences the heat exchange of the room [6,23].

The heat loss due to fencing constructions in the cold season of the year is calculated in a stationary mode assumption, as in winter substantial temperature fluctuations of external air, especially temperature fluctuations of the external side of fencing, are not observed [6].

Considering the fact that temperature mode in the saloons of transport means is rather complex, it has complex mathematic approaches for defining optimal decisions, there is a necessity for conditional perception of a bus saloon as a chamber with a proper capacity to maintain a favorable microclimate and the heat consumption in time, through the constructive elements of a chamber.

A simplified method of calculating values of support (transmission) of the heat comfort in the saloon for a possibility of determining the moment of switching a conditioner at some heat loading, may be applied for city buses and, vice versa, its turning off, when there is no need. Such conditions occur in the warm season of the year due to the excessive input of solar radiation or when there is many passengers even at insufficient temperature indexes of external air.

Due to the complexity of applying automated devices of management of conditioner's work, nonuniform passenger layout in the saloon, large saloon capacity as a room, unstable passenger flow, duration of door opening at technological stops, complexity of the passengers' structure, complexity of determining coefficient of the heat transmission of cladding constructions of the bus saloon, complexity of the heat dissipation index from the passengers, there is a necessity of a simplified approach to determine thermal processes in the saloon via modelling heat loss.

\subsection{Determining the heat loss of a city bus compartment}

Accelerated experimental determining of the heat costs of a bus was carried out according to the methodology [8]. The research conducted directly in the bus saloon implying the autonomous heater of calibrated power.

The main heat factor, determining the microclimate in the city bus saloon, that is characteristic to a short-term passenger presence, is the air temperature [16]. As comfort is a subjective notion, then the efficiency evaluation of the bus saloon thermal loading, equipped by the conditioner, is reasonable to conduct according to temperature and time characteristics of the air in the checkpoints located in the zone of passengers' layout in the compartment and in a driver's cabin (Figure 1). The factor of checkpoints location in the zone of passengers' and driver's head is dominating as the surface of the saloon floor is located at different levels. The figure shows the layout of checkpoints in the process of conducting the experimental research: points 1a-zone of driver's head, $1 \mathrm{~b}$ - zone of passenger's head (at a height of 1.3 and $1.2 \mathrm{~m}$ from the floor, respectively); point $2 \mathrm{a}-$ zone of a standing passenger's head (at a height of $1.75 \mathrm{~m}$ from the floor); points 3a, 3b - zone of sitting/seated passenger's head (at a height of $1.2 \mathrm{~m}$ from the floor).

Heating the bus saloon was conducted via the heater with calibrated heat capacity $\mathrm{N}_{1}$ in the set range of temperatures $\left(t_{\min }{ }^{\circ} \mathrm{C}\right.$ and $\left.t_{\max }{ }^{\circ} \mathrm{C}\right)$. The characteristics of heating $\left(\tilde{\mathfrak{i}}_{1}\right)$ and cooling $\left(\tilde{\mathfrak{i}}_{2}\right)$ are introduced in Figures 2-4.

Characteristics of heating $\left(\tilde{i}_{1}\right)$ and cooling $\left(\tilde{i}_{2}\right)$. Had to be sampled. The process of heating and cooling the saloon of the bus MAZ $t_{\text {max }}^{\circ}=22.5^{\circ} \mathrm{C}$ is shown in Figure 3. At the same time, the temperature of the external environment comprises $t_{\text {ext }}^{\circ}=+7^{\circ} \mathrm{C}$. The heating phase lasted 274, and the whole cycle - $683 \mathrm{~s}$.

Having conducted a range of the cross-sections $\mathrm{C}_{1}, \mathrm{C}_{2}$, $\mathrm{C}_{3} ; \mathrm{L}_{1}, \mathrm{~L}_{2}, \mathrm{~L}_{3} ; \mathrm{K}_{1}, \mathrm{~K}_{2}, \mathrm{~K}_{3}$ (Figure 2, b), the power of the heat 


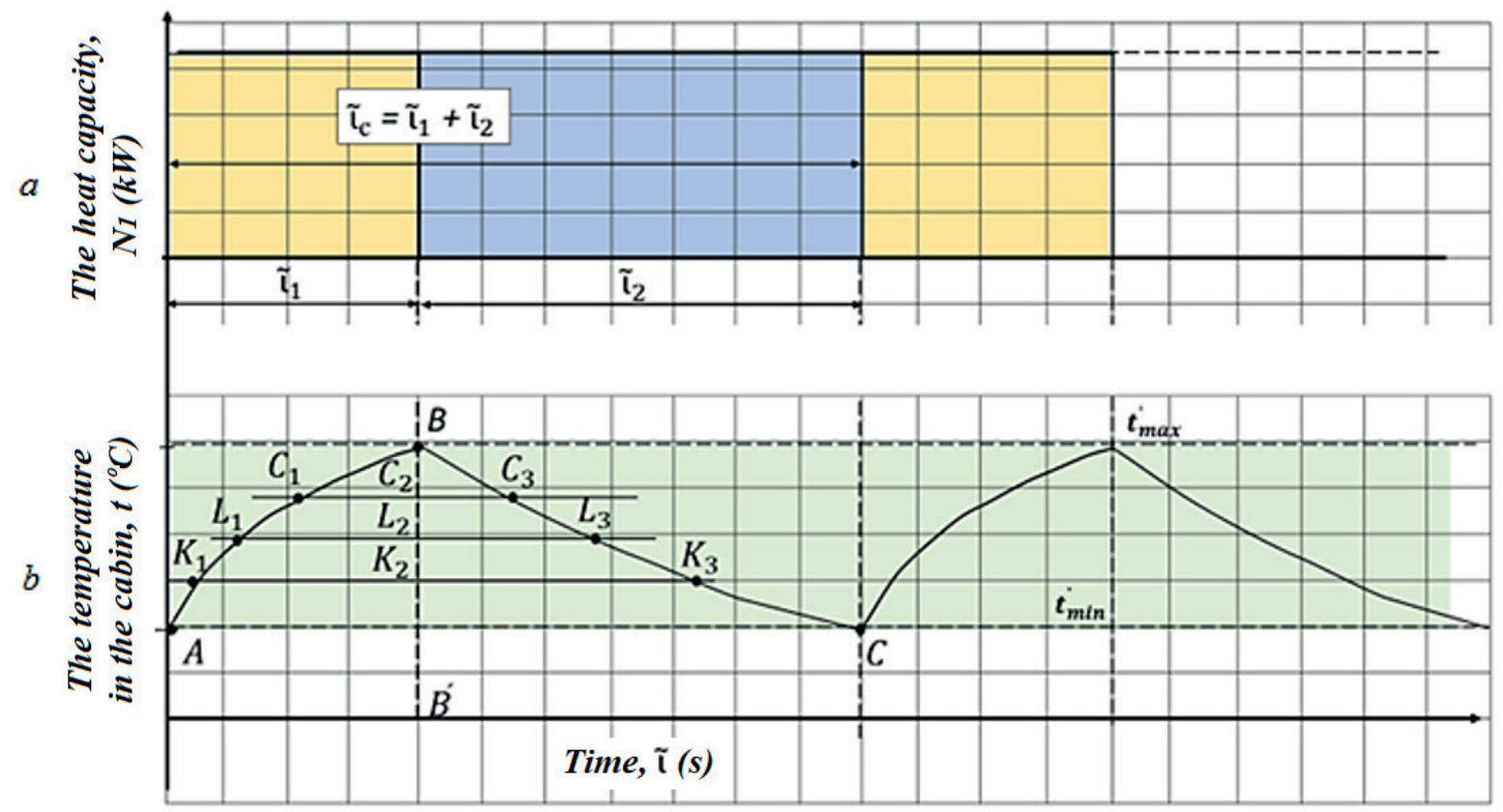

Figure 2 Processes of heating and cooling: $a$-temperature change, $b$ - heat capacity change

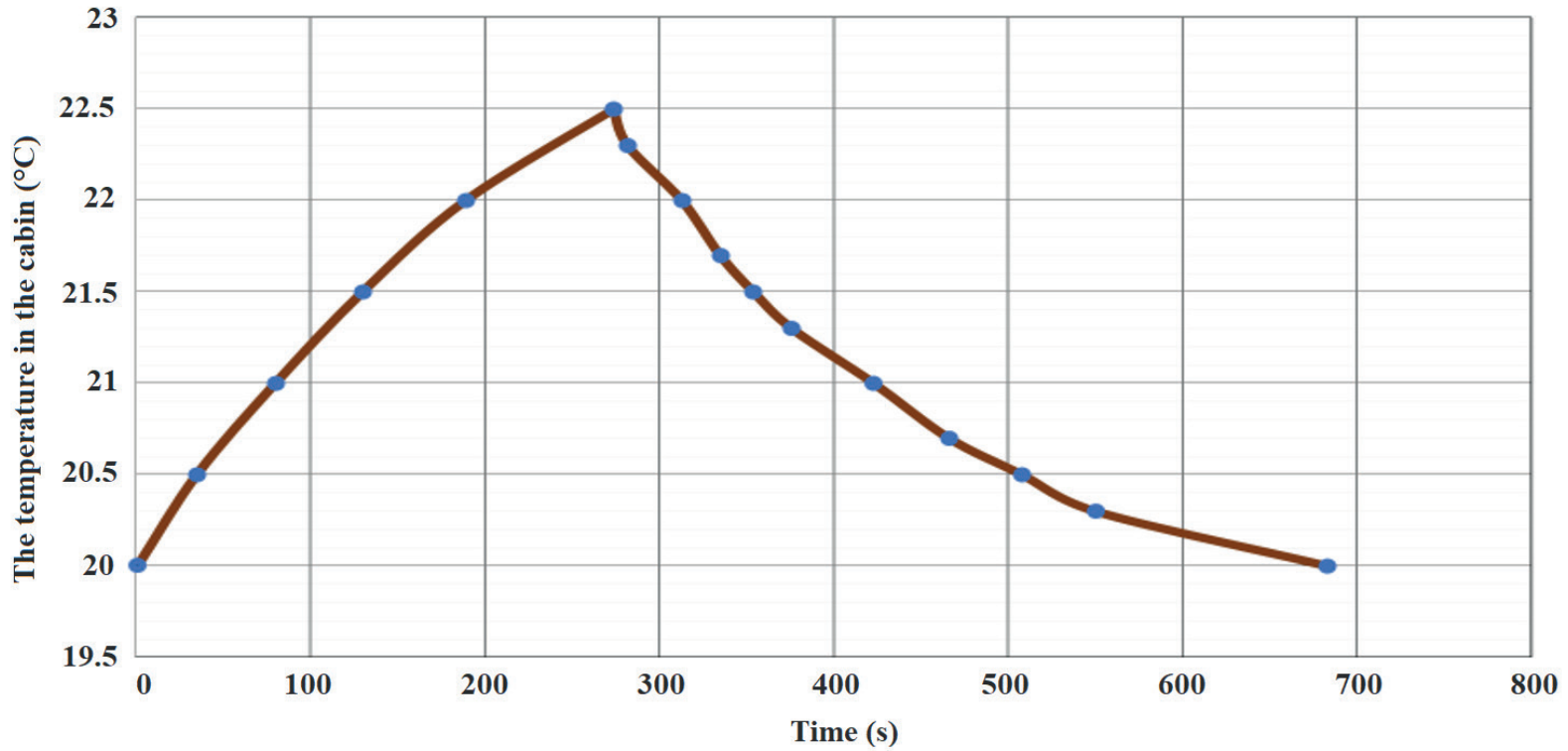

Figure 3 The full cycle of "heating-cooling" the compartment within the range of temperatures $20^{\circ} \mathrm{C}-22.5^{\circ} \mathrm{C}$

costs were calculated as

$$
\mathrm{N}_{t^{\circ} \mathrm{L} 1}=\mathrm{N}_{1} \cdot \frac{L_{1} \cdot L_{2}}{L_{1} t_{2}+L_{2} L_{3}}=\mathrm{N}_{1} \cdot \frac{L_{1} L_{2}}{L_{1} L_{3}}
$$

where $\mathrm{L}_{2}$ is a point of switching a calibrated heater off.

Using the processes of heating and cooling (Figure 2), values of the heat loss power was obtained as $22^{\circ} \mathrm{C} ; 21.5^{\circ} \mathrm{C}$; $21^{\circ} \mathrm{C} ; 20.5^{\circ} \mathrm{C} ; 20^{\circ} \mathrm{C}$, or, taking into account $\mathrm{t}^{\circ}{ }_{\text {ext }}=+7^{\circ} \mathrm{C}$, it results in a sequence $\Delta \mathrm{t}^{\circ}=15^{\circ} \mathrm{C} ; 14.5^{\circ} \mathrm{C} ; 14^{\circ} \mathrm{C} ; 13.5^{\circ} \mathrm{C} ; 13^{\circ} \mathrm{C}$, respectively. The calculation results are shown in Table 1 .

Accordingly,

$\mathrm{N}_{\text {loss }}=\frac{\mathrm{N}_{\text {heat }} \cdot \tilde{l}}{\tilde{l}_{1}+\tilde{\iota}_{2}}=\frac{2 \cdot 274}{683}=0.802 \mathrm{~kW}$.
According to the results obtained (Table 1), the relationship between the heat loss of the compartment and temperature difference in and outside the saloon (external environment) - Figure 4. Resulting from Figure 4, one gets:

$\mathrm{N}_{\text {loss }}=0.272 \cdot \Delta \mathrm{t}^{\circ}-2.72$.

The derivative of Equation (3) reads:

$\frac{\partial \mathrm{N}_{\text {loss }}}{\partial\left(\Delta t^{\circ}\right)}=0.272 \frac{\mathrm{kW}}{\text { degree }}$

where dependency $\frac{\partial \mathrm{N}_{\text {loss }}}{\partial\left(\Delta t^{\circ}\right)}$ is the power of loss in the researched bus compartment, $\frac{\mathrm{kW}}{\text { degree }}$. 
Table 1 Determining dependency of the heat costs on temperature in the compartment and the external environment

\begin{tabular}{|c|c|c|c|c|c|}
\hline no. & $\begin{array}{c}\text { temperature } \\
\text { in the compartment, } \mathrm{t}_{\mathrm{L} 1}^{\circ}\end{array}$ & $\Delta \mathrm{t}^{\circ}=\mathrm{t}_{\mathrm{L} 1}^{\circ}-\mathrm{t}_{\mathrm{ext}}^{\circ}$ & $\begin{array}{l}\mathrm{L}_{1}, \mathrm{~L}_{2} \\
\mathrm{~mm}\end{array}$ & $\begin{array}{l}\mathrm{L}_{1}, \mathrm{~L}_{3} \\
\mathrm{~mm}\end{array}$ & 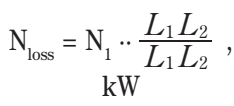 \\
\hline 1 & $22^{\circ} \mathrm{C}$ & $15^{\circ} \mathrm{C}$ & 13.5 & 20 & $2 \cdot \frac{13.5}{20}=1.35$ \\
\hline 2 & $21.5^{\circ} \mathrm{C}$ & $14.5^{\circ} \mathrm{C}$ & 23 & 37 & $2 \cdot \frac{23}{37}=1.24$ \\
\hline 3 & $21^{\circ} \mathrm{C}$ & $14^{\circ} \mathrm{C}$ & 31 & 53 & $2 \cdot \frac{31}{55}=1.12$ \\
\hline 4 & $21^{\circ} \mathrm{C}$ & $13.5^{\circ} \mathrm{C}$ & 38 & 77 & $2 \cdot \frac{38}{77}=0.98$ \\
\hline 5 & $21^{\circ} \mathrm{C}$ & $13^{\circ} \mathrm{C}$ & 44 & 110 & $2 \cdot \frac{44}{110}=0.8$ \\
\hline
\end{tabular}

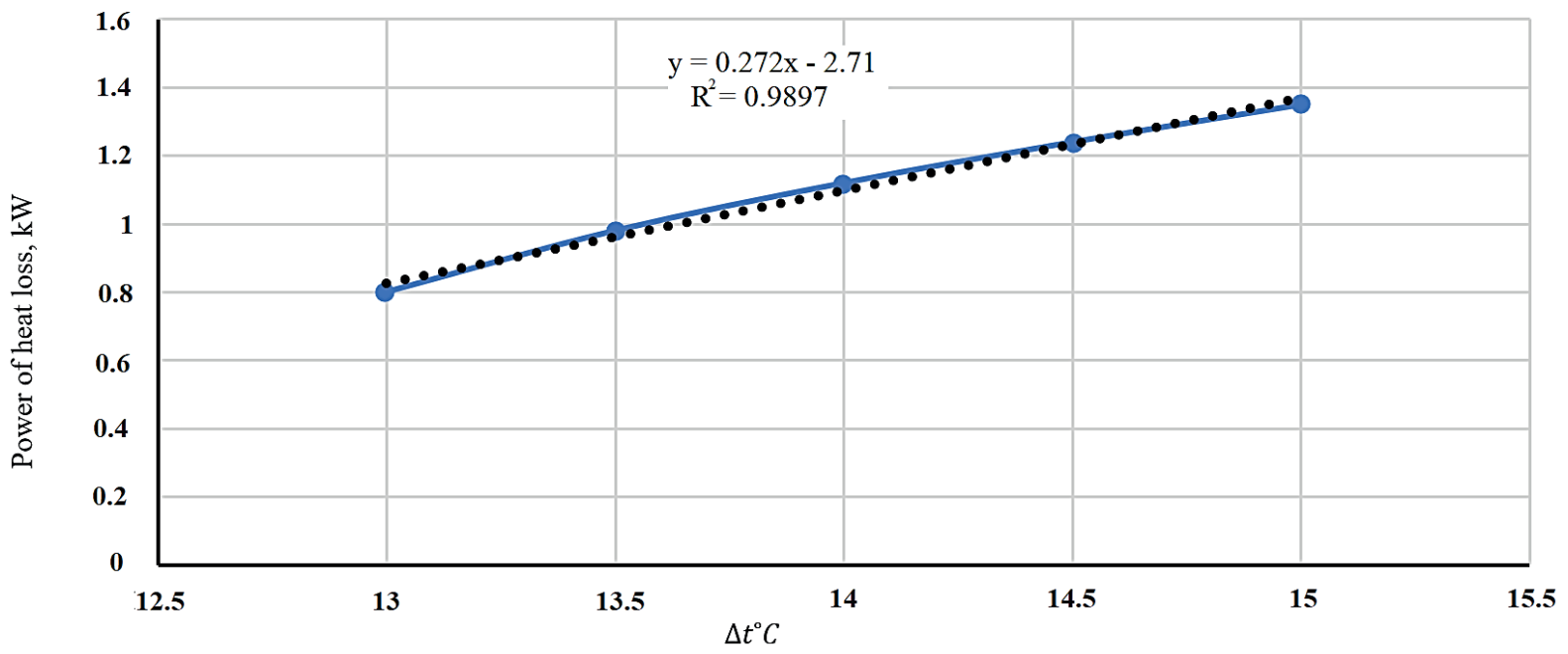

Figure 4 Power of the heat loss of the compartment in terms of $\Delta t^{\circ} \mathrm{C}$

Equations (3) and (4) are a liner approximation of the heat exchange dynamics between the bus compartment and the external environment. By the limitations:

- bus speed is neglected;

- the range of temperature fluctuations in the system "saloon - outside" amounts to:

$10^{\circ} \mathrm{C} \leq \Delta \mathrm{t}^{\circ} \leq 20^{\circ} \mathrm{C}$

- heat flows are considered to be symmetrical $\mathrm{Q}_{1} \cdot\left(\mathrm{t}_{\text {saloon }}^{\circ}>\mathrm{t}_{\text {ext. }}^{\circ}\right)$ and $\mathrm{Q}_{2}\left(\mathrm{t}_{\text {outside }}^{\circ}>\mathrm{t}_{\text {saloon }}^{\circ}\right)$

$\frac{\partial Q_{1}}{\partial t^{\circ}}=\frac{\partial Q_{2}}{\partial t^{\circ}}$

- at $\Delta \mathrm{t}^{\circ}<10^{\circ} \mathrm{C}$, the heat exchange between the saloon and the external environment may be neglected.

Thus, the heat balance in the cycle "heating-cooling" amounts to: when the heater with calibrated power $\mathrm{N}_{1}$ is on, during the time $\tilde{i}_{1}$ the amount of heat, supplied to the saloon (chamber), is:

$\mathrm{Q}_{1}=\mathrm{N}_{1} \cdot \tilde{\mathrm{\imath}}_{1}$.

During that time the temperature in the saloon rises from $t_{\text {min }}^{\circ}$ to $t_{\text {max }}^{\circ}$ in the range set. When it reaches the temperature $t_{\max }^{\circ}$, the heater is off and the saloon cools down from $t_{\text {max }}^{\circ}$ to $t_{\text {min }}^{\circ}$ for the time $\tilde{i}_{2}$. Then, the amount of the heat emitted by the compartment into the external environment amounts to:

$\mathrm{Q}_{2}=\mathrm{N}_{2 \operatorname{costs}} \cdot\left(\tilde{\mathrm{l}}_{1}+\tilde{\mathrm{i}}_{2}\right)$

Having compared $\mathrm{Q}_{1}$ to $\mathrm{Q}_{2}$, one gets:

$\mathrm{Q}_{1}=\mathrm{Q}_{2} ; \mathrm{N}_{1} \tilde{\mathrm{l}}^{=} \mathrm{N}_{2 \exp }\left(\tilde{\mathrm{i}}_{1}+\tilde{\mathrm{i}}_{2}\right)$

The power of the heat costs of the researched object is calculated from Equation (8) as:

$\mathrm{N}_{2}=\mathrm{N}_{1} \frac{\tilde{l}}{\tilde{l}_{1}+\tilde{\iota}_{2}}$.

The obtained results allow determining integrated index of the heat loss - power of heat loss of the researched object - compartment of MAZ -206 bus. It enables to get the power of the heat loss for a necessary range of temperatures $\Delta \mathrm{t}^{\circ}$, as well to establish dependency $\mathrm{N}_{2 \exp }$ on $\Delta \mathrm{t}^{\circ}$. The calculations were performed without taking into account the possible violation of the tightness of the bus saloon. 


\section{Conclusion.}

An approach for determining the models of the heat costs of the bus saloon is proposed that regulates the way of defining the need for the air-conditioner activation of a city bus via the characteristics of the whole system "bus compartment - environment". To obtain the qualitative and quantitative indexes of the temperature change in the bus saloon at the set change of cold air cost, it is worthy to take into account that the heat capacity of the simultaneous air volume is much smaller compared to the sum of the heat capacities of the constructive bodywork elements, seats and partitions. The considered methodology may be used for compartments of other bus models. Studies have confirmed that the cabin interior air inertia does not exceed 1-2 minutes.

This approach can be used for the saloon of other bus models with a larger volume of saloon space, or articulated, for example, Solaris New Urbino 18, using a larger number autonomous calibrated heaters. This is explained by the inertia of the space heating, increased due to the heat perception by the components of the saloon. The setting of the temperature indicators should be delayed for stability of temperature in the whole salon because of the small internal air inertia and the number of recorders to determine the average value in the cabin should be increased.

\section{References}

[1] KURCIK, P., BlatNiCKY, M., DIZO, J., PAVLIK, A., HARUSINEC, J. Design of a technical solution for a metro door system. Transportation Research Procedia [online]. 2019, 40, p. 767-773. ISSN 2352-1465. Available from: https://doi.org/10.1016/j.trpro.2019.07.108

[2] DIZO, J. Evaluation of ride comfort for passengers by means of computer simulation. Manufacturing Technology [online]. 2015, 15(1), p. 8-14. ISSN 1213-2489. Available from: https://doi.org/0.21062/ujep/x.2015/a/1213-2489/MT/15/1/8

[3] MEI, Y., HONGWEN, H., CHO, S., YUI, J. Stochastic dynamic programming of air conditioning system under timevarying passenger condition for electric bus. Energy Procedia [online]. 2016, 104, p. 360-365. ISSN. 1876-6102. Available from: https://doi.org/10.1016/j.egypro.2016.12.061

[4] BOGOLYUBOVA, V. M. Medical rehabilitation (in Russian). Book 1. Moscow: Binom, 2010. ISBN 978-5-9518-0408-2.

[5] ZHUKOVSKIY, S. S. Organized natural ventilation of bus interiors (in Ukrainian). PhD thesis. Lvov: Lviv Polytechnic National University, 1984.

[6] ANANEV, V. A., BAlUEVA, L. N., GAlPERIN, A. D., GORODOV, A. K., EREMIN, M. Y., ZVYAGINTSEVA, S. M., MURASHKO, V. P., SEDYKH, I. V. Ventilation and air conditioning systems. Theory and practice (in Russian). 4. ed. Moscow: Evroklimat, 2003. ISBN 5-89520-044-3.

[7] KRAVCHENKO, O. P., CHUYKO, S. P. Research of bus interior heat balance in the year warm period (in Ukrainian). Scientific Journal of Vladimir Dahl East Ukrainian National University. 2019, 3(251), p. 101-106. ISSN 1998-7927.

[8] GRABAR, I. G., GRABAR, O. I. Method of accelerated energy audit of the investigated volume (drying and refrigeration chambers, industrial and residential premises, other volumes with a given temperature and thermal insulation coating) (in Ukrainian).. Application for a patent for an invention of Ukraine a 201910343 from 15.10.2019.

[9] KULIKOV, Y. A., GRIBINICHENKO, M. V., GONCHAROV, A. V. Car cooling, ventilation and heating systems (in Ukrainian). Monograph. Lugansk: V. Dahl EUNU, 2006. ISBN 966-590-557-0.

[10] MATVEEV, D. V. Development of technology for calculating the heating and ventilation system of a car (in Russian). $\mathrm{PhD}$ thesis. Izhevsk, 2006.

[11] PALUTIN, Y. I. Methodological basis for improving the parameters of the air environment of car interiors (in Russian). PhD thesis. Novgorod, 1997.

[12] TOSUN, E., BILGILI, M., TUCCAR, G., YASAR, A., AYDIN, K. Exergy analysis of an inter-city bus air-conditioning system. International Journal of Exergy [online]. 2016, 20(4), p. 445-464. ISSN 1742-8297. Available from: https://doi. org/10.1504/IJEX.2016.078094

[13] XIANGHAO, S., SHUMIN, F., ZHENNING, L. Analysis of bus passenger based on passenger load factor and in-vehicle time. Springer Plus [online]. 2016, 5(1), 62. ISSN 2193-1801. Available from: https://doi.org/10.1186/s40064-016-1694-7

[14] LEVINSON, R., AKBARI, H., BANWEISS, G., PAN, H., PAOLINI, R., ROSADO, P., SPEARS, M., TAM, J. Cool-colored cars to reduce air-conditioning energy use and reduce $\mathrm{CO}_{2}$ emission. Berkeley: Lawrence Berkeley National Laboratory One Cyclotron Road. 2011.

[15] NORIN, F., WYON. D. Driver vigilance - the effects of compartment temperature. SAE Technical Papers [online]. 1992, 90092. ISSN 0148-7191. Available from: https://doi.org/10.4271/920168

[16] DRAGANOV, B. K., BESSARAB, O. S., DELIISKIY, A. A., LAZORENKO, V. O., MISHCHENKO, A. V., SHELIMANOVA, O.V. Heat engineering: textbook (in Ukrainian). 2. ed. Kiev: Firma Inkos, 2005. ISBN 966-8347-12-9.

[17] VOZNYAK, O. T., SAVCHENKO, O. O., MIRONYUK, CH. V., SHAPOVAL, S. P., SPODINYUK, N. A., GULYAJ, B. I. Heat and gas supply and ventilation (in Ukrainian). Lviv: Lviv Polytechnic National University, 2013. ISBN978-617-607-436-6 
[18] ISO 7730:2005 Ergonomics of the thermal environment - Analytical determinationand interpreta-tion of thermal comfort using calculation of the PMV and PPD indices and local thermal comfort criteria [online] [accessed 2020-05-20]. 2015. Available from: https://www.iso.org/standard/39155.html

[19] DSP 7.7.2.015 - 99. State sanitary rules and norms, hygienic standards of railway rolling stock for passenger transportation (in Ukrainian) [online] [accessed 2020-05-20]. Available from: https://zakon.rada.gov.ua/rada/show/ v0015588-99

[20] WANG, R, DING, G. Advanced Refrigeration and Air Conditioning Technology. Beijing: Science Press, 2002. ISBN7-03-010677-6.

[21] FAYAZBAKHSH, M. A., BAHRAMI, M. Comprehensive modeling of vehicle air conditioning loads using heat balance method. SAE Technical Paper [online]. 2013, 2, 97364. Available from: https://doi.org/10.4271/2013-01-1507

[22] ZHUKOVSKIY, S. S., LABAY, V. Y. Ventilation aerodynamics: a textbook (in Ukrainian). Lviv: Lviv Polytechnic National University, 2003. ISBN 966-553-303-7.

[23] GRABAR, I. G., GRABAR, O. I., GUTNICHENKO, O. A., KUBRAK, YU. O. Percolation-fractal materials: properties, technologies, applications (in Ukrainian). Zhytomir: Zhytomyr Polytechnic State University, 2007. ISBN 978-966-683-135-7. 